\title{
Pengembangan Bahan Ajar Matematika dengan Memanfaatkan Program Geogebra untuk Meningkatkan Kemandirian Belajar
}

\author{
Indri Lestari $^{\left.{ }^{*}\right)}$, Khotimah $^{2}$, \& Eva Fitria Ningsih ${ }^{3}$ \\ ${ }^{1}$ Universitas Serang Raya, ${ }^{2}$ Universitas Serang Raya, ${ }^{3}$ STKIP Pelita Pratama
}

\section{INFO ARTICLES}

\section{Article History:}

Received: 26-11-2019

Revised: 12-12-2019

Approved: 16-12-2019

Publish Online: 29-12-2019

\section{Key Words:}

Geogebra, Kemandirian belajar, Matematika

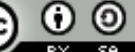 \\ This article is licensed under a Creative Commons Attribution-} ShareAlike 4.0 International License.

\begin{abstract}
This research aims to determine the characteristics of the book which is sufficient for improving independence of student learning, especially on functional subject with Geogebra program. The research method used is research and development, where the research is intended to develop and produce certain product, then test the effectiveness of these products. The subjects in this research were students of SMP Negeri 6 Serang City with a limited scale test conducted on 5 students, while field tests were conducted on 15 students. The conclusions obtained in this research are product feasibility test of $78.8 \%$ according to experts and students who use teaching materials by utilizing the Geogebra program can improve the self regulated learning compared to the students before using the teaching materials.
\end{abstract}

\begin{abstract}
Abstrak: Penelitian ini bertujuan untuk dapat mengetahui karakteristik buku yang memadai bagi peningkatan kemandirian belajar siswa khususnya pada pokok bahasan fungsi dengan memanfaatkan program Geogebra. Metode penelitian yang digunakan yaitu penelitian dan pengembangan. Penelitian ini dimaksudkan untuk mengembangkan dan menghasilkan produk tertentu, serta menguji keefektifan produk tersebut. Subjek dalam penelitian ini adalah siswa SMP Negeri 6 Kota Serang dengan uji skala terbatas dilakukan pada 5 siswa, sedangkan uji lapangan dilakukan terhadap 15 siswa. Simpulan yang diperoleh dalam penelitian ini yakni uji kelayakan produk sebesar 78,8\%. Menurut para ahli dan siswa yang menggunakan bahan ajar dengan memanfaatkan program Geogebra mengalami peningkatan kemandirian belajar dibandingkan dengan siswa sebelum menggunakan bahan ajar.
\end{abstract}

Correspondence Address: Jl. KH. Amin Jasuta No. 15 C, Serang,42111, Indonesia; e-mail: indri.math13@ gmail.com

How to Cite (APA $6^{\text {th }}$ Style): Lestari I., Khotimah., \& Ningsih E.F. (2019). Pengembangan Bahan Ajar Matematika dengan Memanfaatkan Program Geogebra untuk Meningkatkan Kemandirian Belajar. JKPM (Jurnal Kajian Pendidikan Matematika), 5 (1): 49-60

Copyright: Lestari, I., Khotimah., \& Ningsih, E. F., (2019)

Competing Interests Disclosures: The authors declare that they have no significant competing financial, professional or personal interests that might have influenced the performance or presentation of the work described in this manuscript. 


\section{PENDAHULUAN}

Menurut Undang-Undang Nomor 20 Tahun 2003 tentang Sistem Pendidikan Nasional, manusia yang berkualitas yaitu manusia terdidik yang beriman dan bertakwa kepada Tuhan Yang Maha Esa, berakhlak mulia, sehat, berilmu, cakap, kreatif, mandiri, dan menjadi warga negara yang demokratis dan bertanggung jawab. Begitu juga siswa harus memiliki sifat mandiri dalam belajar. Kemandirian siswa dapat dilihat jika seorang siswa sudah dapat belajar sendiri tanpa mengandalkan guru atau orang lain. Jika siswa sudah dapat menerapkan hal itu maka prestasi siswa akan lebih meningkat karena mereka akan lebih berinisiatif untuk menyelesaikan persoalan yang dihadapi dengan mandiri. Kemandirian pada manusia dewasa bersifat psikologis bukan merupakan suatu bakat yang dimiliki individu tapi dapat dikembangkan dengan baik pada diri seseorang melalui latihan yang dilakukan berkesinambungan. Kemandirian belajar dapat ditingkatkan melalui aktivitas pembelajaran yang relevan. Pemilihan metode pembelajaran yang memungkinkan individu untuk dapat menumbuhkembangkan kemandirian belajarnya, sangat penting untuk diimplemetasikan.

Seperti halnya diungkapkan oleh Basir (2010) menyatakan bahwa kemandirian belajar diartikan sebagai suatu proses belajar yang terjadi pada diri seseorang, dan dalam usahanya untuk mencapaitujuan belajar orang tersebut dituntut untuk aktif secara individu atau tidak bergantung pada orang lain, termasuk tidak bergantung pada gurunya. Tidak halnya dengan anak SD maupun SMP, mereka masih mengalami kesulitan dalam belajar mandiri jika tidak menemukan metode yang tepat. Upaya dalam memberikan pembelajaran yang menyenangkan maka perlu adanya media pembelajaran yang menarik. Menurut Hosnan (2014: 63) media pembelajaran adalah segala sarana atau bentuk komunikasi nonpersonal yang dapat dijadikan wadah dari informasi pelajaran yang akan disampaikan kepada peserta didik, serta dapat menarik minat dan perhatian, sehingga tujuan dari belajar dapat tercapai dengan baik. Dengan demikian media pembelajaran adalah segala sesuatu yang dapat digunakan sebagai alat bantu komunikasi pengantar dalam proses pembelajaran, yang membawa konsep atau informasi tentang materi pelajaran.

Bahan ajar juga sangat dibutuhkan oleh guru untuk pendamping siswa dalam belajar. Bahan ajar adalah segala bentuk bahan yang digunakan untuk membantu guru atau instruktur dalam melaksanakan proses pembelajaran di kelas menurut National Centre for Competency Based Training (Praswoto, 2011: 16). Pandangan dari ahli lainya mengatakan bahwa bahan ajar adalah seperangkat materi yang disusun secara sistematis, baik tertulis maupun tidak tertulis, sehingga tercipta lingkungan atau suasana yang memungkinkan peserta didik untuk belajar. Bahan ajar yang dipakai yakni bahan ajar digital yang dalam hal ini berisikan materi fungsi dalam format file $p d f$. Pemakaian bahan ajar ini menggunakan bantuan komputer sehingga berbagai ilustrasi maupun simulasi yang ada dalam bahan ajar ini dapat berjalan maksimal sehingga tercipta interaktivitas secara langsung antara siswa dan bahan ajar. Lebih lanjut Mahmudi (2011) juga mengemukakan bahwa inovasi pembelajaran dengan bantuan komputer sangat baik untuk diintegrasikan dalam pembelajaran konsep-konsep matematika, terutama yang menyangkut transformasi geometri, kalkulus, statistika, dan grafik fungsi. Media pembelajaran yang digunakan dalam kasus ini yakni menggunakan bahan ajar dengan memanfaatkan aplikasi Geogebra. Menurut Hohenwarter (Mahmudi, 2011:2), program Geogebra sangat bermanfaat bagi guru maupun siswa. Tidak sebagaimana pada penggunaan programkomersial yang biasanya hanya bisa dimanfaatkan di sekolah, Geogebra dapat diinstal pada komputer pribadi dan dimanfaatkan kapan dan di manapun oleh siswa maupun guru. Bagi guru, Geogebra menawarkan kesempatan yang efektif untuk mengkreasi lingkungan belajar online interaktif yang memungkinkan siswa mengeksplorasi berbagai konsep-konsep matematis.

Hasil temuan peneliti sebelumnya menyatakan adanya pengaruh kemandirian belajar siswa dengan menggunakan bahan ajar matematika bersuplemen komik (Guntur, Muchyidin, \&Winarso. 2017). Rumusan masalah yang ingin diangkat yakni apakah terdapatnya peningkatan kemandirian belajar siswa sebelum dan sesudah uji coba produk. Berdasarkan latar belakang tersebut, tujuan dari penelitian ini ialah 
untuk mengetahui tingkat kelayakan produk bahan ajar menurut para ahli dan terdapatnya peningkatan kemandirian belajar siswa sebelum dan sesudah uji coba produk.

\section{METODE}

Penelitian ini bertujuan untuk menghasilkan suatu produk yaitu sebuah bahan ajar dengan memanfaatkan program Geogebra yang bisa dimanfaatkan dalam pembelajaran, sehingga penelitian ini menggunakan rancangan penelitian pengembangan. Sugiyono (2010: 407), penelitian untuk pengembangan (Research and Development) adalah penelitan untuk mengembangkan dan menghasilkan produk tertentu, dan menguji keefektifan produk tersebut. Metode penelitian meliputi beberapa tahap seperti langkah-langkah yang dikembangkan Sukmadinata (2008: 184) memodifikasi langkah-langkah pelaksanaan penelitian dan pengembangan Borg dan Gall terdiri atas tiga langkah, yaitu: (1) Studi Pendahuluan, (2) Pengembangan Produk, dan (3) Uji Produk. Pada penelitian ini, pengembangan bahan ajar yakni studi pendahuluan dan uji coba pengembangan produk.. Studi pendahuluan mencangkup studi pustaka, survei lapangan, penyusunan draft awal produk (membuat kisi-kisi angket kemandirian belajar, desain produk awal), uji ahli (ahli multimedia, ahli bidang studi, ahli pendidikan), revisi 1. Sedangkan pada tahap uji coba pengembangan produk meliputi uji coba terbatas dan uji lapangan. Pada tahap ini dilakukan uji coba produk dalam skala kecil (terbatas) terhadap kelompok siswa yang terdiri dari 5 orang siswakelas IX SMP Negeri 6 Kota Serang. Dari hasil uji coba terbatas ini dilakukan revisi jika diperlukan berdasarkan penilaian yang diberikan siswa mengenai bahan ajar yang diberikan kemudian dikonsultasikan kembali pada para ahli. Setelah itu dilakukannya uji lapangan dimana dilakukan pada 15 orang siswakelas IX SMP Negeri 6 Kota Serang. Pada uji lapangan ini, instrumen non test yang digunakan adalah angket kemandirian belajar siswa yang diberikan sebelum dan sesudah diberikan produk bahan ajar yang telah dikembangkan untuk mengetahui peningkatan kemandirian belajar siswa.

Instrumen non-tes yang digunakan adalah angket kemandirian belajar siswa diberikan sebelum dan sesudah pemberian produk bahan ajar untuk mengetahui peningkatannya. Skala kemandirian belajar siswa yang digunakan adalah skala likert. Angket yang digunakan pada penelitian ini yaitu angket tertutup sesuai dengan skalalikert yang dikemukakan oleh Riduwan (2008: 54) Skala ini berkarakteristik dengan cara memberikan tanda silang $(\mathrm{X})$ atau tanda checklist $(\sqrt{ })$. Skala likert digunakan untuk mengukur sikap, pendapat dan persepsi seseorang atau sekelompok orang tentang fenomena sosial (Riduwan, 2010: 38). Setiap siswa diminta untuk menjawab pertanyaan-pertanyaan dengan jawaban Selalu, Sering, Kadangkadang, Jarang dan Tidak Pernah. Untuk pertanyaan positif maka dikalikan dengan skor Selalu $=5$, Sering $=4$, Kadang-kadang $=3$, Jarang $=2$, Tidak Pernah $=1$ dan sebaliknya untuk pertanyaan negatif dengan skor Selalu $=1$, Sering $=2$, Kadang-kadang $=3$, Jarang $=4$, Tidak Pernah $=5$.

Data yang dianalisis dalam penelitian ini adalah data kualitatif. Data kualitatif diperoleh dari angket kemandirian belajar siswa yang disi oleh siswa sebelum dan sesudah pemberian produk bahan ajar. Datadata yang telah dijelaskan di atas dianalisis menggunakan statistik deskriptif. Statistik deskriptif adalah statistik yang memberikan gambaran atau deskripsi suatu data yang dilihat dari nilai rata-rata, standar deviasi, maksimum, minimum, sum, range, kurtosis dan skewness (kemencengan distribusi). Statistik deskriptif mendeskripsikan data menjadi sebuah informasi yang lebih jelas dan mudah dipahami (Ghozali, 2016:19). Data hasil kemudian diolah dengan menghitung rata-rata skor angket setiap siswa dan ditafsirkan dalam kategori. Hal ini dilakukan untuk mengetahui kecenderungan sikap siswa terhadap produk bahan ajar yang memanfaatkan program Geogebra.

Selanjutnya, data hasil kemudian diolah dengan menghitung rata-rata skor angket setiap siswa. Hal ini dilakukan untuk mengetahui kecenderungan sikap siswa terhadap produk bahan ajar yang memanfaatkan program Geogebra. Rata-rata skor angket siswa ditafsirkan Hidayat (Darmalasari, 2009: 39-40) dengan kriteria sebagai berikut: 
Tabel 1. Kriteria Kemandirian Belajar Siswa

\begin{tabular}{cc}
\hline Rata-rata Skor Angket Siswa & Kriteria \\
\hline $0 \leq \bar{x}_{\mathrm{a}}<1,5$ & Sangat kurang \\
\hline $1,5 \leq \bar{x}_{\mathrm{a}}<2,5$ & Kurang \\
\hline $2,5 \leq \bar{x}_{\mathrm{a}}<3,5$ & Cukup \\
\hline $3,5 \leq \bar{x}_{\mathrm{a}}<4,5$ & Baik \\
\hline $4,5 \leq \bar{x}_{\mathrm{a}}<5$ & Sangat baik \\
\hline
\end{tabular}

\section{HASIL}

\section{A. Merancang dan Membangun Bahan Ajar Berbasis Kemandirian Belajar dengan Memanfaatkan Program Geogebra}

Merancang dan membangun bahan ajar berbasis kemandirian belajar dengan bantuan Geogebra sebagai salah satu media yang dapat digunakan oleh siswa dalam pembelajaran agar siswa dapat belajar secara mandiri. Selain itu, bahan ajar juga dapat dimanfaatkan oleh guru sebagai bahan ajar dalam pembelajaran matematika khususnya materi fungsi. Desain awal pembuatan bahan ajar berbasis kemandirian belajar dengan bantuan Geogebra adalah materi fungsi yang isinya berupa teks narasi dan disertai dengan berbagai ilustrasi dan animasi, serta video-video untuk memperjelas dalam penyampaian materi.

Produk akhir bahan ajar matematika dengan memanfaaatkan program Geogebra terdiri dari 2 subbahasan pada materi relasi yaitu pengertian relasi dan menyatakan relasi, kemudian 6 subbahasan pada materi fungsi yaitu pengertian fungsi, grafik fungsi, notasi dan nilai fungsi, menentukan rumus fungsi, sifat fungsi, dan macam-macam fungsi. Adapun gambaran produk akhir bahan ajar yaitu (1) Media penyimpan dengan CD-R dan kertas 80 gram; (2) Ukurannya B5 (16cm x $24 \mathrm{~cm})$; (3) Ketebalannya 56 halaman (bolak balik + cover); (4) Jenis huruf yakni Times new Roman, Algerian, Showcard, Gothic, dan Snap ITC; (5) Format PDF; (6) Materinya fungsi berisi teks narasi di dalamnya terdapat konflik kognitif, ilustrasi gambar, dan terdapat ilustrasi Geogebra yang dibuat untuk meningkatkan kemandirian belajar siswa; (7) Software yang dibutuhkan yakni Adobe Reader 9 atau versi di atasnya dan Java Application.

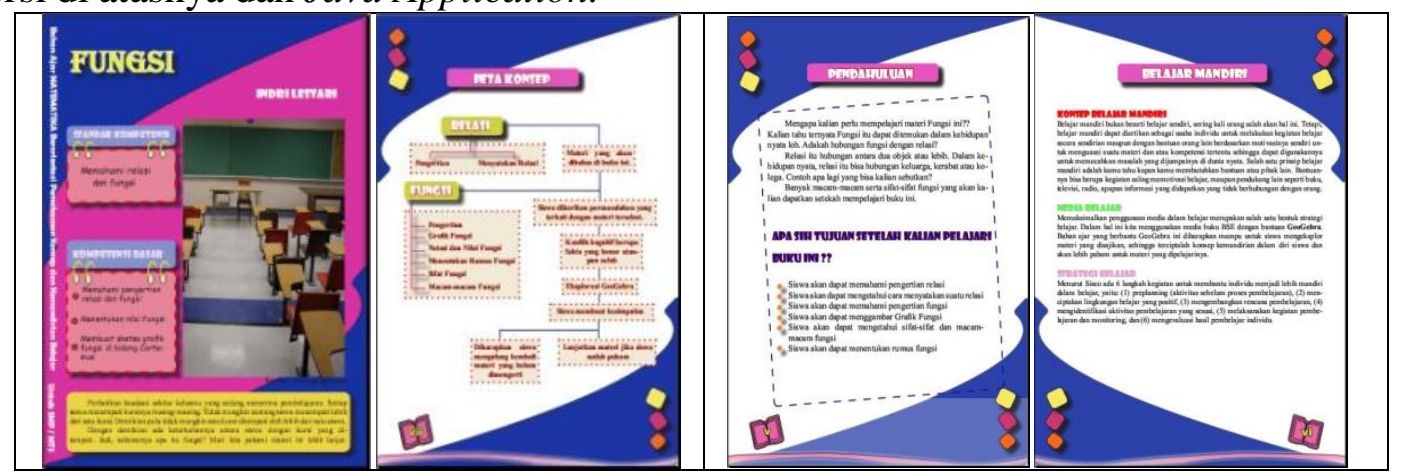




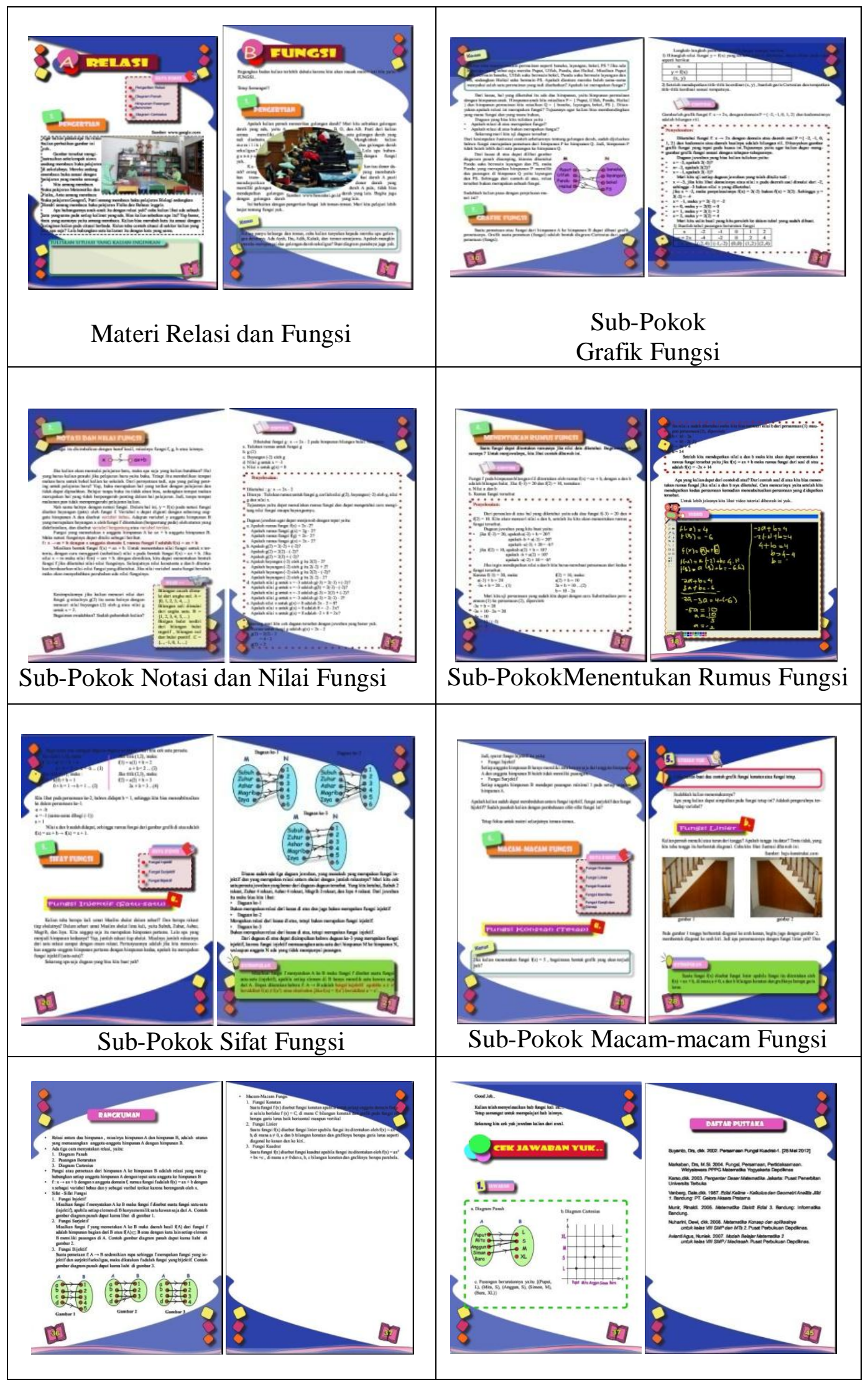

Gambar 1. Draf Akhir Bahan Ajar 
Dari desain awal dilakukan uji Ahli Multimedia, uji Ahli Matematika, dan uji Ahli Pendidikan, kemudian dilakukan perbaikan berdasarkan penilaian para ahli yaitu dengan merevisi isi bahan ajar dengan memperdalam konflik kognitif dalam setiap bahasannya, agar sesuai dengan indikator kemandirian belajar dan melihat kembali jika ada kesalahan dalam penulisan. Setelah dilakukan perbaikan sesuai dengan komentar dan saran para ahli, dan dinyatakan sudah cukup bagus dan siap dilakukan uji skala terbatas.

Uji skala terbatas dilakukan terhadap 5 orang siswa di SMP Negeri 6 Kota Serang kelas IX. Dari hasil uji ini, didapatkan hasil yang cukup baik, dan berdasarkan temuan di lapangan, siswa terlihat antusias pada saat menggunakan bahan ajar. Setelah dilakukan revisi dari hasil uji skala terbatas. Kemudian dilanjutkan pada uji lapangan yang melibatkan 15 siswa di SMP Negeri 6 Kota Serang kelas IX dan hasilnya pun sudah baik. Hasil temuan di lapangan pun siswa terlihat antusias dikarenakan baru melihat program Geogebra yang mudah dan menyenangkan. Berdasarkan uji ahli, uji skala terbatas dan uji lapangan maka diperoleh draf akhir dari bahan ajar.

Pada proses penyajian materi, bahan ajar matematika berbasis pemahaman konsp dan kemandirian belajar serta berbantuan Geogebra yang dikembangkan ini menggunakan konsep yang mengarahkan siswa untuk dapat memahami konsep matematika secara mudah secara mandiri. Terrdapat empat siklus kemandirian belajar yang mendasari penerapan pembelajaran secara mandiri. Menurt Shuck dan Zimmerman (Fahinu , 2007: 47) keempat tahap siklus tersebut adalah :

\section{a. Tahap Perencanaan}

Pada tahap ini, siswa menetapkan langkah-langkah untuk belajar, yaitu (1) menganalisis tugas belajar, (2) menentukan tujuan belajar, dan (3) merencanakan strategi belajar. Tahap perencanaan tersebut terdapat pada semua alur dalam mempelajari bahan ajar ini, jadi siswa diarahkan untuk memahami materi secara mandiri.

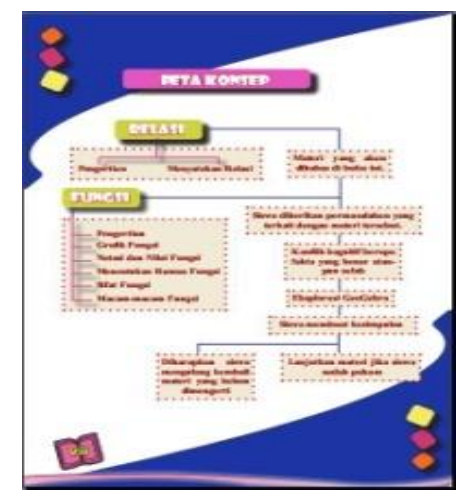

Gambar 2. Tahap Perncanaan

\section{b. Tahap Mentoring}

Pada tahap ini, siswa menerapkan strategi belajar yang telah dibuat dengan terus-menerus dimonitor agar mengarah ke tujuan belajar. Siswa memantau kegiatan belajarnya sambil mengajukan pertanyaan pada diri sendiri. Apakah strategi yang dilaksanakan sesuai dengan rencana? Apakah saya kembali kepada kebiasaan lama? Apakah saya tetap memusatkan diri? Dan apakah strategi telah berjalan dengan baik?. Tahap mentoring terdapat pada semua sub pokok bahasan dalam mempelajari bahan ajar ini sehingga siswa diarahkan untuk mengeluarkan pendapatnya, mengecek kembali apakah pendapat yang dikeluarkannya benar atau salah karena dalam bahan ajar ini terdapat konflik kognitif yang berupa fakta-fakta yag bernilai benar dan salah, dan terdapat applet Geogebra yang interaktif dan dijadikan pilihan untuk menyelesaikan permasalahan pada materi yang sedang dipelajari, sehingga akhirnya siswa mampu menarik kesimpulan dari apa yang sedang dipelajari. Tahap mentoring ini dapat digambarkan pada bahan ajar misalnya pada halaman 10, halaman 11, dan halaman 12. 


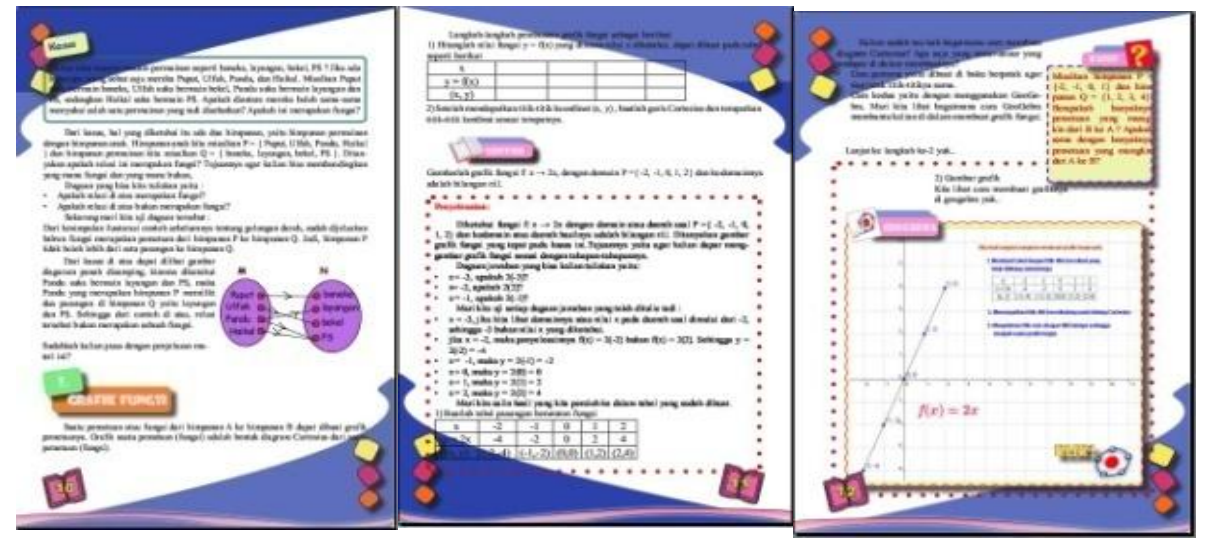

Gambar 3. Tahap Mentoring

\section{c. Tahap Evaluasi}

Pada tahap ini, siswa menentukan seberapa baik strategi belajar yang dipilih dan bagaimana pencapaian tujuan belajar tersebut. Tahap ini memuat kegiatan memeriksa bagaimana jalannya strategi: Apakah strategi telah dilaksanakan dengan baik? (Evaluasi proses); Hasil belajar apa yang telah dicapai? (Evaluasi produk); dan sesuaikah strategi dengan jenis tugas belajar yang dihadapi?. Tahap evaluasi terdapat pada semua sub pokok bahasan dalam mempelajari bahan ajar ini. Misalnya pada halamanan 28 dan halaman 35.

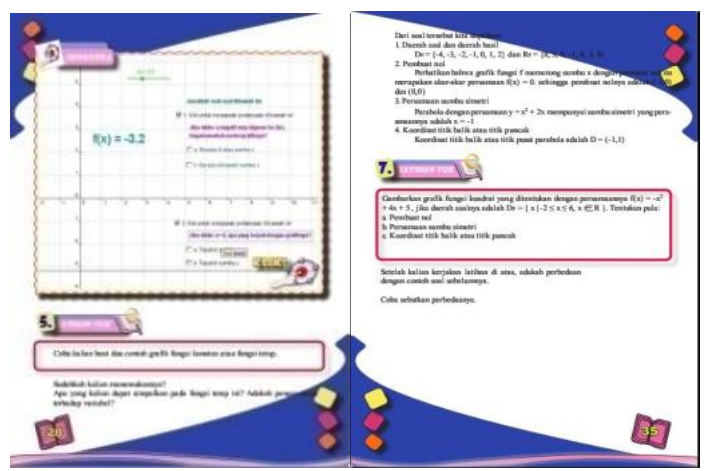

\section{d. Tahap Refleksi}

\section{Gambar 4. Tahap Evaluasi}

Tahap refleksi menyediakan hubungan-hubungan antara ketiga tahapan dalam memahami pelajaran (pengetahuan metakognitif). Tahap evaluasi hanya berada di setiap akhir subbahasan misalnya di halaman 25.

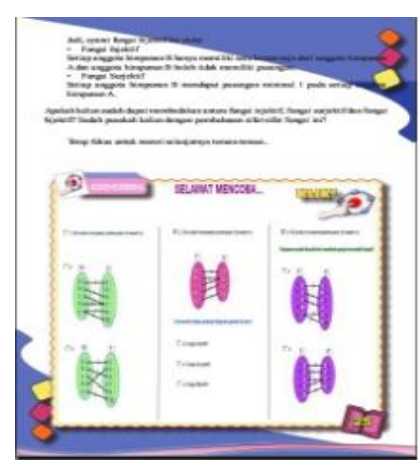




\section{Gambar 5. Tahap Refleksi}

Uji ahli dilakukan sebelum uji produk ke lapangan, ada tiga ahli uji bahan ajar yakni ahli multimedia pembelajaran dimana terdapat aspek arsitektur penampilan, integritas warna, background, animasi dan ilustrasi, serta struktur penempatan applet Geogebra. Skor 3 kategori cukup diberikan untuk aspek struktur penempatan applet Geogebra, skor 4 kategori baik diberikan untuk aspek arsitektur penampilan, background, serta animasi dan ilustrasi, sedangkan skor 5 (sangat baik) diberikan pada aspek integritas warna. Uji ahli matematika terdiri dari aspek keakuratan acuan pustaka, rangkuman. Keduanya memiliki skor 3 dengan kategori cukup, serta aspek keakuratan konsep dan definisi, keakuratan fakta dan data, keakuratan contoh dan kasus, keakuratan gambar, diagram, dan ilustrasi, keakuratan istilah, keakuratan notasi, simbol, dan icon, kesesuaian dengan karakteristik mata pelajaran, glosarium, daftar indeks masing-masing memiliki skor 4 dengan kategori baik. Terakhir dilakukan oleh ahli pendidikan terdiri dari aspek merangsang kemampuan analisis siswa dengan skor 3 kategori cukup, sedangkan aspek kelengkapan penyajian, kesesuaian dengan tingkat perkembangan intelektual siswa, bahasa yang digunakan sesuai dengan kematangan sosial emosional peserta didik, mempermudah siswa memahami konsep matematika, mempermudah siswa dalam mengklasifikasikan objek-objek menurut sifat-sifat tertentu sesuai dengan konsepnya, mempermudah siswa dalam menggunakan, memanfaatkan, dan memilih posedur atau operasi tertentu dalam matematika, mendorong keinginan untuk mencari informasi lebih jauh, membuat siswa lebih mandiri dalam belajar masing-masing memiliki skor 4 untuk kategori baik, serta aspek meningkatkan interaksi siswa dengan bahan ajar memiliki point 5 untuk kategori sangat baik. Kemudian setiap skor pada tiap ahli dihitung dan dijadikan persentase. Pada ahli multimedia mendapatkan $80 \%$, pada ahli matematika mendapatkan skor $76,36 \%$ sedangkan pada ahli pendidikan mendapatkan skor $80 \%$. Kemudian ketiganya dijumlahkan dan dibagi 3, maka rata-rata uji kelayakan bahan ajar di atas yakni $78,8 \%$.

\section{B. Kemandirian Belajar Sebelum dan Setelah Menggunakan Bahan Ajar Matematika dengan Memanfaatkan Program Geogebra}

Angket kemandirian belajar yang diberikan sebelum menggunakan bahan ajar bertujuan untuk mengetahui seberapa besar kemandirian belajar siswa yang terbentuk terhadap pembelajaran matematika, sedangkan angket kemandirian belajar yang diberikan setelah menggunakan bahan ajar bertujuan untuk mengetahui bagaimana kemandirian belajar siswa setelah melakukan pembelajaran dengan menggunakan bahan ajar. Sebelum dilakukannya uji lapangan, pengujian produkdilakukan pada skala terbatas dimana skor kemandirian belajar pada saat uji terbatas disajikan dalam Tabel 2.

Tabel 2. Skor Kemandirian Belajar pada Uji Terbatas

\begin{tabular}{cccc}
\hline No. & Subyek & Skor Sebelum & Skor Sesudah \\
\hline 1. & Siswa 1 & 2,9 & 3,3 \\
\hline 2. & Siswa 2 & 3,4 & 3,67 \\
\hline 3. & Siswa 3 & 4,08 & 4,08 \\
\hline 4. & Siswa 4 & 3,16 & 3,25 \\
\hline 5. & Siswa 5 & 2,25 & 2,83 \\
\hline
\end{tabular}

Setelah melaksanakan uji skala terbatas kepada 5 orang kemudian diadakan revisi produk baru kemudian menyebarkan angket ke 15 siswa dalam uji lapangan. Skor kemandirian belajar siswa pada uji lapangan dapat terlihat pada tabel 3: 
Tabel 3.Skor Kemandirian Belajar pada Uji Lapangan

\begin{tabular}{ccc}
\hline Subyek & Skor Sebelum & Skor Sesudah \\
\hline Siswa 1 & 3 & 3,67 \\
\hline Siswa 2 & 2,83 & 3 \\
\hline Siswa 3 & 3,17 & 4 \\
\hline Siswa 4 & 3,42 & 3,92 \\
\hline Siswa 5 & 3,67 & 4,08 \\
\hline Siswa 6 & 3,25 & 3,33 \\
\hline Siswa 7 & 3,08 & 3,08 \\
\hline Siswa 8 & 3,33 & 3,5 \\
\hline Siswa 9 & 2,33 & 3,67 \\
\hline Siswa 10 & 2,83 & 3,5 \\
\hline Siswa 11 & 3 & 3,33 \\
\hline Siswa 12 & 2,83 & 3,25 \\
\hline Siswa 13 & 3,33 & 3,42 \\
\hline Siswa 14 & 3,08 & 3,17 \\
\hline Siswa 15 & 2,33 & 2,67 \\
\hline
\end{tabular}

Sebaran data variabel kemandirian belajar dapat dilihat pada daftar distribusi frekuensi di tabel 4:

Tabel 4.Distribusi Frekuensi Skor Pada Uji Terbatas dan Uji Lapangan

\begin{tabular}{cccccc}
\hline \multirow{2}{*}{ Interval } & \multirow{2}{*}{ Kategori } & \multicolumn{2}{c}{ Persentase Uji Terbatas } & \multicolumn{2}{c}{ Persentase Uji Lapangan } \\
\cline { 3 - 6 } & & Sebelum & Sesudah & Sebelum & Sesudah \\
\hline Di atas 52 & Sangat Mandiri & 0 & 0 & 0 & 0 \\
\hline $42-51$ & Mandiri & $1(20 \%)$ & $2(40 \%)$ & $1(6,67 \%)$ & $7(46,67 \%)$ \\
\hline $32-41$ & Cukup Mandiri & $3(60 \%)$ & $3(60 \%)$ & $12(80 \%)$ & $8(53,33 \%)$ \\
\hline $22-31$ & Belum Mandiri & $1(20 \%)$ & 0 & $2(13,33 \%)$ & 0 \\
\hline $12-21$ & Tidak Mandiri & 0 & 0 & 0 & 0 \\
\hline & Jumlah & $5(100 \%)$ & $5(100 \%)$ & & $15(100 \%)$
\end{tabular}

Terlihat dari tabel diatas adanya peningkatan kemandirian belajar dari kelima belas siswa sebelum dan setelah penggunaan bahan ajar. Kriteria hasil kemandirian belajar siswa tiap indikator dapat terlihat pada tabel 5:

Tabel 5. Kriteria Hasil Kemandirian Belajar Siswa Tiap Indikator

\section{Indikator}

Mampu mengelola strategi belajar sendiri

Mampu mengelola waktu belajar

Mampu menilai aktivitas belajarnya sendiri

Mampu mengatasi kesulitan memahami bahan ajar

Mampu mengukur kemampuan dan hasil belajar sendiri

\section{Kriteria Kemandirian}

Awal

Kurang

Cukup

Cukup

Baik

Cukup
Kriteria Kemandirian

Akhir

Cukup

Cukup

Cukup

Baik 
Interaksi siswa dengan bahan ajar

Cukup

Baik

\section{PEMBAHASAN}

Media merupakan salah satu faktor yang mendukung keberhasilan proses pembelajaran di sekolah karena dapat membantu proses penyampaian informasi dari guru kepada siswa atau sebaliknya (Arda, Saehana, \& Darsikin, 2015). Menurut Association of Education and Communication Technologi (Arsyad, 2016), media sebagai segala bentuk dan saluran yang digunakan untuk menyampaikan pesan atau informasi. Menurut Thomas (dalam Omodara \& Adu, 2014) in education, media are the symbol systems that teachers and learners utilise in representing knowledge and technologies are the tools that allow them to share their knowledge representations with others. Salah satu media yang dapat digunakan dalam pembelajaran yaitu media komputer. Pembelajaran menggunakan komputer sangat dinikmati oleh siswa, selain itu komputer juga dapat membuat pembelajaran menjadi lebih efektif dan efisien (Utama, Nilaswati, \& Vionanda, 2012).

Menurut Wedemeyer (Rusman, 2011: 353), siswa yang belajar secara mandiri mempunyai kebebasan untuk belajar tanpa harus menghadiri pembelajaran yang diberikan guru atau pendidik di kelas. Tugas guru dalam proses belajar mandiri ialah menjadi fasilitator, yaitu menjadi orang yang siap memberikan bantuan kepada siswa bila diperlukan. Guru dapat memberikan fasilitas/ mengkondisikan sekolah dengan memilih strategi atau model yang tepat, atau berbentuk bantuan dalam menentukan tujuan belajar, memilih bahan dan media belajar, serta dalam memecahkan kesulitan yang tidak dapat pecahkan siswa sendiri sehingga dapat membantu meningkatkan kemandirian belajar siswa. Menurut Jhonson (2007: 153-154) proses pembelajaran mandiri paling baik diuji dari dua perspektif yang berbeda, tetapi sangat berhubungan. Pertama, pembelajaran mandiri mengharuskan siswa untuk memiliki pengetahuan dan keahlian tertentu. Mereka harus tahu dan mampu melakukan hal-hal tertentu yaitu mengambil tindakan, bertanya, membuat keputusan mandiri, berpikir kreatif dan kritis, memiliki kesadaran diri, dan bisa bekerja sama. Kedua, pembelajaran mandiri mengharuskan siswa untuk melakukan hal-hal tersebut yaitu menggunakan pengetahuan dan keahlian, dalam urutan yang pasti satu langkah secara logis mengikuti langkah yang lain. Pengetahuan dan keahlian yang dibutuhkan agar berhasil dalam pembelajaran mandiri.

Geometri merupakan salah satu bidang matematika yang mempelajari titik, garis, bidang dan ruang, serta sifat-sifat, ukuran-ukuran, dan keterkaitannya satu dengan yang lain. Menggambarkan dan menganalisis geometri dalam matematika mudah dilakukan dengan menggunakan media aplikasi GeoGebra. Transformasi geometri dapat dilakukan melalui GeoGebra yang mencakup translasi, refleksi, rotasi, dan dilatasi (Nur'aini, Harahap, Badruzzaman, \& Darmawan, 2017). Bahan ajar smartbook dapat meningkatkan kemandirian belajar siswa (Mulyani, Hidayat, \& Lisnawati, 2015)

Setelah dilakukan pengelompokan kemandirian belajar siswa, diperoleh bahwa kemandirian belajar siswa sebelum dan sesudah menggunakan bahan ajar meningkat lebih baik. Hal ini menunjukan pembelajaran matematika dengan menggunakan bahan ajar berbasis kemandirian belajar siswa serta berbantuan Geogebra mengalami peningkatan. Peningkatan kemandirian belajar siswa setelah menggunakan bahan ajar mengalami peningkatan yang cukup baik dimana dapat dilihat dari peningkatan skor rata-rata tiap siswa terhadap indikator yang diberikan maupun kriteria kemandirian siswa. Angket skala sikap kemandirian siswa pada penelitian ini difokuskan pada enam indikator yaitu mampu mengelola strategi belajar sendiri, mampu mengatur waktu dan tempat belajar, mampu menilai aktivitas belajarnya sendiri, mampu mengatasi kesulitan memahami bahan ajar, mampu mengukur kemampuan dan hasil belajar sendiri, interaksi siswa dengan bahan ajar.

Analisis skala sikap akan dibagi berdasarkan enam indikator sebagai berikut. (1) Mampu Mengelola Strategi Belajar Sendiri, secara umum rata-rata skor pernyataan keseluruhan siswa dalam indikator mampu mengelola strategi belajar sendiri sebelum menggunakan bahan ajar awalnya sebesar 2,27 dengan kategori kurang dan setelah menggunakan bahan ajar mengalami peningkatan sebesar 2,87 dengan kategori cukup, (2) Mampu Mengatur Waktu dan Tempat Belajar, secara umum rata-rata skor pernyataan keseluruhan 
siswa dalam indikator mampu mengatur waktu dan tempat belajar sebelum menggunakan bahan ajar awalnya 2,8 dengan kategori cukup dan setelah menggunakan bahan ajar mengalami peningkatan sebesar 3 masih dengan kategori yang sama yaitu cukup. (3) Mampu Menilai Aktivitas Belajarnya Sendiri, secara umum, rata-rata skor pernyataan keseluruhan siswa dalam indikator mampu menilai aktivitas belajarnya sendiri sebelum menggunakan bahan ajar awalnya sebesar 2,9 dengan kategori cukup dan setelah menggunakan bahan ajar mengalami peningkatan sebesar 3,47 masih dengan kategori yang sama yaitu cukup, (4) Mampu Mengatasi Kesulitan Memahami Bahan Ajar, secara umum, rata-rata skor pernyataan keseluruhan siswa dalam indikator mampu mengatasi kesulitan memahami bahan ajar sebelum menggunakan bahan ajar awalnya sebesar 3,5 dengan kategori baik dan setelah menggunakan bahan ajar mengalami peningkatan sebesar 3,8 masih dengan kategori yang sama yaitu baik, (5) Mampu Mengukur Kemampuan dan Hasil Belajar Sendiri, secara umum, rata-rata skor pernyataan keseluruhan siswa dalam indikator mampu mengukur kemampuan dan hasil belajarnya sendiri sebelum menggunakan bahan ajar awalnya sebesar 3,27 dengan kategori cukup dan setelah menggunakan bahan ajar mengalami peningkatan sebesar 3,67 dengan kategori baik, (6) Interaksi Siswa dengan Bahan Ajar, secara umum rata-rata skor pernyataan keseluruhan siswa dalam indikator mampu berinteraksi dengan bahan ajar sebelum menggunakan bahan ajar awalnya sebesar 3,4 dengan kategori cukup dan setelah menggunakan bahan ajar mengalami peningkatan sebesar 3,84 dengan kategori baik.

Bagi peneliti yang akan mengembangkan sebuah bahan ajar matematika yang bersifat interaktif dan melakukan penelitian yang berkaitan dengan bahan ajar diharapkan untuk membuat bahan ajar pada pokok bahasan yang lain, menambahkan game yang bersifat edukatif dan berhubungan dengan materi yang sedang dibahas untuk membantu siswa belajar dengan lebih menyenangkan sekaligus melatih siswa berpikir cepat dan tepat. Sedangkan bagi para pengembang multimedia pembelajaran yang ingin melanjutkan mengembangkan bahan ajar berbasis kemandirian belaja pada materi bangun ruang sisi datar agar melakukan perbaikan pada bagian applet Geogebra dan lebih memunculkan lagi konflik kognitifnya.

\section{SIMPULAN}

Bahan ajar berbasis pemahaman konsep siswa dengan bantuan Geogebra ini dibuat melalui tahap penelitian dan pengembangan dengan tingkat kelayakan 78,8\% dari uji Ahli Multimedia, Ahli Matematika dan Ahli Pendidikan.Kemandirian belajar siswa sebelum dan setelah uji coba produk terdapat peningkatan, meskipun tidak terlalu besar. Pada uji skala terbatas peningkatan persentase kemandirian belajar siswa sebelum dan sesudah menggunakan bahan ajar sebesar5,34\%, sedangkan pada uji lapangan peningkatan persentase kemandirian belajar sebelum dan sesudah menggunakan bahan ajar sebesar 8,11\%.

\section{UCAPAN TERIMA KASIH}

Terima kasih kepada Bapak Uripto, S.Pd., M.Pd. yang telah mengizinkan dilakukannya penelitian di SMP Negeri 6 Kota Serang. Kepada Bapak Ibu dan saudara-saudaraku yang telah mendukung dan mendoakan suksesnya penelitian ini. Terima kasih juga kepada pihak yang membantu yang tidak bisa saya sebut satu per satu.

\section{DAFTAR RUJUKAN}

Arda, S. Saehana, \& Darsikin. (2015). Pengembangan Media Pembelajaran Interaktif Berbasis Komputer untuk Siswa SMP Kelas VIII, e-Jurnal Mitra Sains, III (1). 
Arsyad, A. (2016). Media Pembelajaran. Jakarta: PT Rajagrafinda Persada.

Basir, La Ode. (2010). Kemandirian Belajar atau Belajar Mandiri. (Diakses dari http://www.smadwiwarna.net/website/data/artikel/kemandirian.htm/ tanggal 6 Februari 2018)

Departmen Pendidikan Nasional. (2003). Undang-Undang No. 20 tahun 2003. Tentang Sistem Pendidikan Nasional. Jakarta : Depdiknas.

Ghozali,Imam. 2016. Aplikasi Analisis Multivariete dengan Program (IBM SPSS). Edisi 8. Badan Penerbit Universitas Diponegoro. Semarang

Guntur M., Muchyidin A., \&Winarso W. (2017). Pengaruh Penggunaan Bahan Ajar Matematika Bersuplemen Komik terhadap Kemandirian Belajar Siswa. EduMa, 6(1), 43-51

Hohenwarter, M., et al. (2008). Teaching and Calculus with free dynamic mathematics software Geogebra.International Congress on Mathematical Education 16: 1-9

Hosnan, M. (2014). Pendekatan Saintifik dan Kontekstual dalam Pembelajaran Abad 21. Bogor: Ghalia Indonesia.

Johnson , B.J. dan Alwasilah A.C. (2007). Contextual Teaching and Learning. Bandung: Mirzan Learning Center.

Mahmudi. (2011). Pemanfaatan GeoGebra dalam Pembelajaran Matematika. Jurusan Pendidikan Matematika FMIPA UNY

Mulyani, L., Hidayat, A., \& Lisnawati, C. (2015). Pengembangan Bahan Ajar Smartbook Berbasis Sains untuk Meningkatkan Kemandirian Belajar. Jurnal Pendidikan dan Pembelajaran Ekonomi Akutansi, I (1), 22-32

Nuraini,I.L., Harahap, E., Badruzzaman, F. H., \& Darmawan, D. (2017). Pembelajaran Matematika Geometri Secara Realistis dengan GeoGebra. Jurnal Matematika 16 (2), 5

Omodara, \& Adu. (2014). Relevance of Educational Media and Multimedia Technology for Effective Service Delivery in Teaching and Learning Processes. Journal of Research \& Method in Education (IOSR-JRME) , IV (2), 48

Praswoto, A. (2011). Panduan Kreatif Membuat Bahan Ajar Inovatif. Yogyakarta: Pusat Diva Press.

Riduwan. (2010). Skala Pengukuran Variabel-variabel Penelitian. Bandung: Alfabeta.

Rusman. 2011. Model-Model Pembelajaran Mengembangkan Profesionalisme Guru. Jakarta: PT Raja Grafindo Persada.

Sugiyono. (2010). Metode Penelitian Pendidikan Pendekatan Kuantitatif, Kualitatif, dan R\&D. Bandung: Alfabeta

Sukmadinata, Nana Syaodih. (2008). Metode Penelitian Pendidikan. Bandung: PT. Remaja Rosdakarya

Utama, N. P., Nilawasti, \& Vionanda, D. (2012). Penggunaan Macromedia Flash 8 pada Pembelajaran Dimensi Tiga. Jurnal Pendidikan Matematika , I, 51-59. 